\title{
Symptomatic management of a child with cyclic vomiting syndrome
}

\author{
Shanthan Mettu, ${ }^{1}$ Dwitha Animireddy, ${ }^{1}$ Pratej Kiran Kanumuri, ${ }^{2}$ Radhika Muppa ${ }^{1}$
}

${ }^{1}$ Department of Pedodontics and Preventive Dentistry, Panineeya Mahavidyalaya Institute of Dental Sciences and Research Centre, Hyderabad, Telangana, India ${ }^{2}$ Panineeya Institute of Dental Sciences and Hospital, Hyderabad, Telangana, India

\section{Correspondence to}

Dr Pratej Kiran Kanumuri, pratejkiran@gmail.com

Accepted 3 August 2016

\section{(a) CrossMark}

To cite: Mettu $S$, Animireddy D, Kanumuri PK, et al. BMJ Case Rep Published online: [please include Day Month Year] doi:10.1136/bcr-2016216499

\section{DESCRIPTION}

Cyclic vomiting syndrome (CVS) is a functional disorder characterised by recurrent, self-limited episodes of intractable nausea and vomiting that are not caused by any specific disease. ${ }^{1}$ The episodes occur at variable intervals with prodromal phase of nausea and pallor. The mean age of onset is 3.9 years and the mean number of attacks per year is 4 . The aetiology is unknown, but it is possibly because of a dysregulation of the neuroendocrine system, exaggerated cardiovascular responses to postural change and other stimuli that may be associated with the onset of gastrointestinal symptoms. ${ }^{2}$

A 27-month-old patient reported to the department of paediatric dentistry with symptoms of swollen gums and loose teeth in the lower front teeth region (figure 1). A detailed history revealed that the patient suffered from repeated episodes of fever and vomiting and was diagnosed with CVS. Blood investigations showed neutropenia, eosinophilia, thrombocytosis and the red blood cells on the peripheral blood smear appeared hypochromatic with anisopoikilocytosis, microcytes and ovalocytes.

Intraoral examination revealed generalised inflammation of the attached and marginal gingiva with grade II mobility of 71 and 81 . Oral prophylaxis, debridement and irrigation with hydrogen peroxide were performed. Local application of metronidazole gel and sodium monoflourophosphate mouthwash with the importance of oral hygiene maintenance was advised and the patient was recalled after 1 week.

The symptoms subsided and patient was instructed to continue the same regimen for a

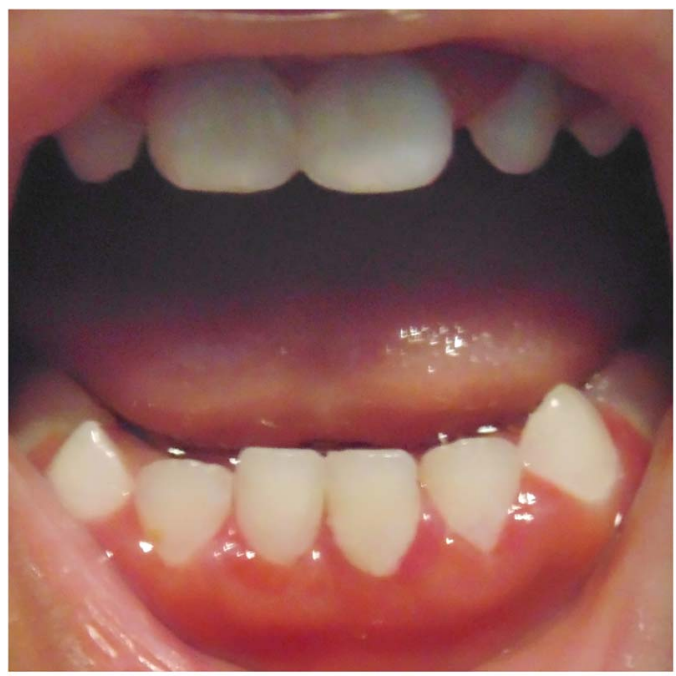

Figure 1 Preoperative photograph-inflamed gingiva and accumulation of plaque.

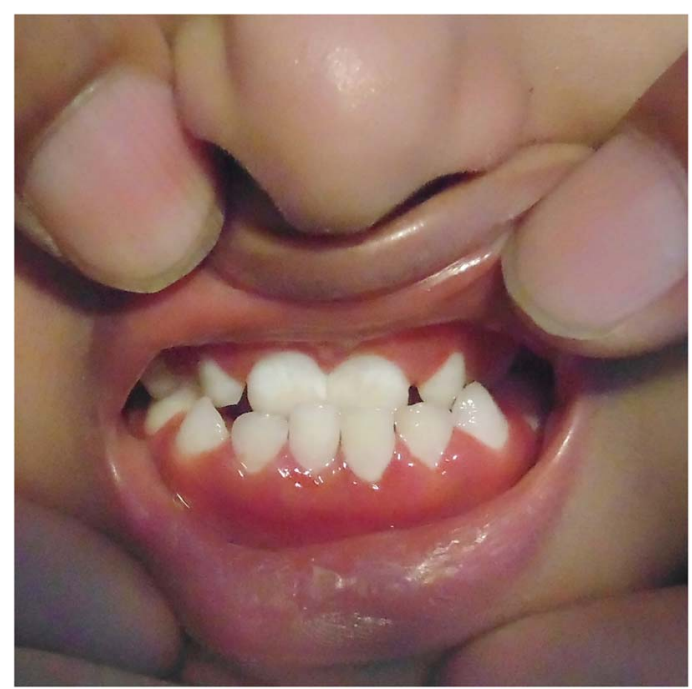

Figure 2 Postoperative photograph.

fortnight. On the subsequent visit, the inflammation had drastically come down and there was no mobility of 71 and 81 (figure 2).

\section{Learning points}

The oral findings in the patients suffering from cyclic vomiting syndrome (CVS) may vary and it has not been explored in the literature to a greater extent.

- CVS can cause tooth sensitivity and erosion, cavities, periodontal disease, dry mouth, salivary gland enlargement and trauma to the oral tissue.

- The objective of the article is to review the important aspects of this disease, and discuss its potential significance as related to the oral findings and complications.

Contributors SM performed the treatment. DA collected articles. PKK took photographs. RM prepared the manuscript.

Competing interests None declared.

Patient consent Obtained.

Provenance and peer review Not commissioned; externally pee reviewed.

\section{REFERENCES}

1 Forbes D, Fairbrother S. Cyclic nausea and vomiting in childhood. Aust Fam Physician 2008;37:33-6.

2 Lee LY, Abbott L, Moodie S, et al. Cyclic vomiting syndrome in 28 patients: demographics, features and outcomes. Eur I Gastroenterol Hepatol 2012;24:939-43. 
Copyright 2016 BMJ Publishing Group. All rights reserved. For permission to reuse any of this content visit http://group.bmj.com/group/rights-licensing/permissions.

BMJ Case Report Fellows may re-use this article for personal use and teaching without any further permission.

Become a Fellow of BMJ Case Reports today and you can:

- Submit as many cases as you like

- Enjoy fast sympathetic peer review and rapid publication of accepted articles

- Access all the published articles

- Re-use any of the published material for personal use and teaching without further permission

For information on Institutional Fellowships contact consortiasales@bmjgroup.com

Visit casereports.bmj.com for more articles like this and to become a Fellow 